\title{
Reasons and Ramifications of Tardy Marriages among Educated Muslim Women Folk in Indian Controlled Kashmir: An Introspection from Social Psychology Standpoint
}

\author{
Dr. Suriya Hamid ${ }^{1}$ \\ ${ }^{1}$ Faculty- Psychology- GSD, College for Women, Prince Sultan University, Riyadh, Kingdom of Saudi \\ Arabia. \\ Correspondence: Dr. Suriya Hamid, Faculty- Psychology- GSD, College for Women, Prince Sultan University, \\ Riyadh, Kingdom of Saudi Arabia.
}

Received: June 18, 2017

Accepted: December 9, 2017

Online Published: December 10, 2017

doi:10.5539/ijps.v9n4p109

URL: http://doi.org/10.5539/ijps.v9n4p109

\begin{abstract}
Since times immemorial, marriage is considered as an act by virtue of which two individuals make their relationship manifest in terms of a bond that putatively lasts for life time. Spiritually, marriages are believed to be settled in heavens and solemnized on earth. This metaphoric scenario is often practiced other way round in the valley of Kashmir. As a matter of fact, the process of seeking a life associate and its consolidation in terms of marriage is so cumbersome and unenviable that it often leads the women folk of Kashmir into cyclic rethinking about its eudaemonia. In the anticipation of endorsements for a happy married life with the tendency of zeroing risk factors, the dingy psycho-evolved system that is dominant now-a-days leads the Kashmir phratry towards the manifestation of tardy marriages. This piece of research work aims to ascertain the reasons and axiomatic ramifications that lead to tardy marriages among educated Muslim Women folk in Kashmir Valley. This study is also an attempt to comprehend the social stratification and cultural dynamics of Kashmir as is introspected from social psychology standpoint. This paper unfolds the coalescing systematics of major issues and complexities of tardy marriages in order to present a strategic arduous solution to counter and castigate this imperil that creates distortion and soreness in the social fabric of Kashmir.
\end{abstract}

Keywords: Tardy Marriages, Kashmir Social Psychology, Social Stratification, Muslim Women

\section{Introduction}

Kashmir world over is known for its natural landscape beauty and is usually referred to as paradise on earth. It is situated in the lap of the mighty Himalayas. And it is a heterogeneous state in its existence, with a number of geographical regions and sub regions, representing people from different ethnic backgrounds, professing diverse religions, language and culture making it a vibrant specimen of integrity amidst diversity. Kashmir valley has been the most important of the territories as it was one of the prominent trade depots of the silk route that connected Central Asia and Europe via Arab belt. It was the pivot, the centre of civilization, culture, power, politics and movements which influenced and was influenced by developments, migrations, trade and politics in adjoining regions. Among various religious groups Muslims are the majority community with 68.31 per cent of total population while Hindus constitute the largest minority community. Other religious minorities i.e. Sikhs, Buddhists, Christians, Jains etc. are in meager number. Kashmiri Muslims have their own distinct culture chronically imitated and adapted from different areas primarily of the silk route.

From centuries, people who traversed through Kashmir preferred to settle in the valley because of the serene climatic conditions and social soberness of general population. From kings to commons, from traders to travelers, people from different regions and cultural backgrounds settled and owed Kashmir Valley in its true spirit, thereby making Kashmir Valley a place of diversity; yet a coherent cultural mix. This steady owingness and vicissitude seems factually the primary reason that Kashmir is still a matter of contention between three nuclear armed neighboring nations. Understandingly Kashmir's prevailing cultural mix in its interaction is generally referred to as Kashmiri Society. Unconsciously, Kashmiri society as a whole witnessed cultural intrusion from different corners of influence, be it in social, political, economical domains. Kashmiri society as a matter of fact positioned itself as a platform for the Iranian culture to tessellate with that of Arab and the mingling of it with 
that of Indian sub content. It is fascinating to find the traditions of Central Asia, crafts of Iran, religious temperament of Arab, festivals of Indian sub continent etc. all at one place- Kashmir. Similarly, one is impressed to witness languages such as Kashmiri, Persian, Urdu, Arabic, Hindi, English, Sanskrit, Gojri, Dogri, Balti, Punjabi, Pahadi, Tibetan etc. all being spoken at one place viz. Kashmir - a geographic area of merely 222,236 Sq. Kms.

As true with nationalities world over, Kashmiri society too has witnessed transformation. Be it in social, political, cultural, economical capacities and in reality this change in social patterns affected the fundamental bottom-line of each and every aspect of life. These scenarios specifically prevailed in the practices, rituals, values and norms of marriage; in general the social-psyche of the population transformed. Marriage in Kashmiri society is generally perceived as a cornerstone in ones pursuit of existence. As a sacred institution of accord, marriages usually fetch paramount importance centering every aspect of life on it. Avowedly, societies change when mindset of masses changes. From psychology standpoint, Kashmiri diaspora adapted everything that it could from vicinities of influence. Its general population is considered to carry the most fertile brains and hence relegated to the community of wisdom and knowledge. There is a belief in the west, that original inhabitants of Kashmir are actually the lost tribes of Noah's Ark. Thereby paving the way for some researchers to find similarities in the genetic composition of Jews and Kashmiris.

Marriage psychology in Kashmir too has passed the stringent test of time. Everything in its conception changed with due course of time. New thoughts, new beliefs, new rituals all experiments and gradually evolved into what is commonly found today in Kashmir's contemporary society. Maturity of the society is directly proportional to its consciousness and awareness. To reach the state of full consciousness requires ample time. So is true with the concept of the articulation of marriages in Kashmiri society. In the past, marriages used to be very simple in all aspects and endeavors. It was considered as a mini aspect of life or just the means of furthering progeny. But now times have changed, so has the human cogitate nature. Marriages are now considered as value addition processes in the endless pursuit of self actualization. In Kashmir, the process of seeking a life associate and its consolidation in terms of marriage is so cumbersome and unenviable that it often leads the women folk of Kashmir to cyclic rethinking about its eudaemonia. In the anticipation of endorsements for a happy married life with the tendency of zeroing risk factors, the dingy psycho-evolved system that is dominant now-a-days leads the Kashmir phratry towards the manifestation of tardy marriages. In Kashmir for the past two to three decades, the average age of marriage for male has increased from 24 to 32 and in females from 21 to 28 . It is the matter of grave concern for social scientists. In 2010, a research study conducted by the Department of Sociology, University of Kashmir, revealed that 55 percent of the total population of Kashmir never actually gets married even after attaining the standard marriageable age. This premise has given rise to depression and instability among the youth. Be it physical, psychological or emotional, it slumps all the three components of a healthy life. Political instability, poverty, modern education, dowry system, unemployment, corruption, caste consideration, decline in sex ratio, apprehensional thinking, information overloading syndrome are believed to be the major reasons for tardy marriages in Kashmir. Many people conceive advent of modernization; unhealthy customs, traditions and irreligious attitude in the society to have played their part in pushing up the average marrying age. Local population is forced to think and belief, that had it not been the God's will to keep a biological limit in terms of age to produce offsprings, female folk in Kashmir would never marry, rather they would prefer to search and explore continuously till all parameters of marriage are secured and are made satisfactory to the bride in particular. This is the point where from arises the rudiments of tardy marriages, this in layman's language is often referred to as late marriages or delayed marriages. The process of change in the social structure is an inevitable universal social reality. The changes in the last few decades are so rapid and far reaching that many thinkers look upon this as a new era in human history. The processes of urbanization and liberalization have brought about many socio- psychological changes in the attitudes and values of the people. The most striking one is the emancipation of educated women from their traditional bound ethos challenging the institution of marriage and family.

\section{Significance of Study}

Lot of research has been carried out and ample volumes of literature are available on the subjects revolving around tardy marriages. Since tardy marriages are prevailing particularly in developing nations, most of the significant research works and scientific studies that have been carried out in this regard deal with the factors that incubate tardy marriages specifically in third world countries. The prime focus of these studies so far has been on the origin, dynamics, implications in the system that lead to the factors responsible for their intra-complexity, and more often the orientation of these studies have been carried either from sociology, anthropology, economics or cultural paradigms. Nappingly, very less or negligible research has been carried out 
from psychology standpoint. It is in the fundamental importance and interest of the intelligentsia to study the brains and rationale behind the factors that ultimately lead to the tardy marriages. Scientifically, it would be appropriate to understand the naturally inculcated thinking of general masses in order to ascertain those influences that lead to such thinking and hence the origin of the criterias that often lead to late marriages or simple to say delayed marriages. By and large this topic is fetching lot of attraction and attention from Indian as well as Western social scientists, that they have started paying special attention to the analysis of the dynamic social system and the changes taking place therein. In the recent past, research wise some attention has also been paid to study and understand the socio-cultural life of Muslim community that constitute the largest minority in India as a country and the majority in a state viz. Kashmir.

In reference to Kashmir, more often the research in these parameters and references have been carried out by outsiders who predominantly were either lacking knowledge about the basic instincts or the DNA composition (behavioral aspect) of the Kashmiris. And it is evident that they either had time scarcity or lack of patience to dig deep into the grass root levels. No better can anyone claim to understand their culture rather than themselves. Essentially, in the search of factual and competent research outcomes in psychological gist the Kashmiri society has to introspect within and this introspection would be of paramount importance because no one would understand Kashmiri psyche better than the subject themselves. As a colligate fact, the socio-cultural study on Kashmiri Muslims has also come to the forefront in the development of sociological literature especially in India today. Dabla et. al $(1999,2009 \&$ 2010) has contributed immensely in this field. According to their findings from sociology viewpoint, there are five major reasons of late marriages in Kashmir Valley viz. poverty, dowry considerations, un-employment, conflict situation and caste system. This study primarily focused on the underlying factors and their structural hierarchy in the establishment of the ecumenical practice called tardy marriages. No points in reference to the factors were brought in the light of psychological aspect as such.

Wani et. al. (2013) has attempted to study social stratification among Muslims in Kashmiri society. The contemporary Kashmiri society was studied on the basis of Caste, Class and Power. In the findings, caste system was found to be radically different from caste system in Indian society. In Kashmir Valley, the rigid aspect was missing and very few people were ready to attach any importance to ascribed status. Like all other societies, in Kashmir also there exist various forms of social stratification among the Muslim community. However, historically a shift is witnessed from one form of stratification to other. According to the 1921 census of India, majority of the Muslims in the Indian sub-continent in general and Kashmir in particular are the descendents of locals who changed their religion from Hinduism to Islam. Hence some Muslims and non-Muslims say that these local Muslims who originally converted to Islam individually or in large groups consciously or unconsciously brought into their practice of Islam, their former Hindu caste practices and customs.

Likewise, Mohiuddin et. al (1995) stressed on the point that the lower status of women in society morphologically fetched low wage rates than men in all fields and their large number of responsibilities of family are due to abandonment, divorce, etc. in the developing countries. Women's lower status not only affects their work but also other aspects of their lives such as education and health. In general, men and women of today are willingly stepping out of their traditionally demarcated roles and moving towards a more egalitarian concept of marriage. Some of the changing patterns in intimate relationship that are currently posing challenges to the traditional model of marriage are, increasing acceptability of singlehood, increasing popularity of cohabitation and increasing rate of divorce. Various reform movements, social legislations and opening of modern occupational roles for women have created new outlooks. The institution of marriage is getting shifted more to the needs of individuals than as the social and religious obligations. Legally speaking, the traditional ideals of marriage have been replaced with a new set in which marriage is no longer a social or a family concern. It is purely a personal affair leading a man and woman to seek social, psychological and economic happiness by pursuing their own free, will.

It is observed that in Kashmir Valley the prevailing juxtaposition of late marriages is not only infested in illiterate or underprivileged class but also in educated and elite lot too. This sparks sarcasm in general and as such this psyche need to be studied and explored thoroughly. It is crystal clear and evident from the facts and references remarked so far that there is an extreme requirement for research on this topic that fascinates academicians, practioners and social scientists even at local levels. The topic "tardy marriages among educated muslim women in Kashmir" is completely unexplored from the socio-psychology perspective. Factually, this is the first study of its kind that directly makes an attempt to explore this matter in reference to context. The study of reasons and ramifications of tardy marriages among Kashmiri Muslims female folk is of greater importance and requires systematic enquiry at different modes and levels of investigation for understanding this phenomenon from socio-psychology standpoint. The focus of the study provides a comprehensive depiction of 
the patterns of psychological transformation and potential influences that lead to delayed marriages among Kashmiri Muslims women folk. The study also tries to throw light on the ramifications and aftermaths of tardy marriages in Kashmir valley.

\section{Methodology}

Studying human nature and its underlying influences in reference to tardy marriages is in fact the topic of much importance to Kashmiris as well as much interest to the social scientists, politicians, philosophers, social activists and intellectuals. The proposed study is on important topic i.e. Tardy Marriages. This topic has been dealt many a time before but the researchers have either concluded on undertaking only influencing factors into consideration or they have not researched it from social-psychology outlook. There is always an unremitting scope for more and more of quality research on this particular topic.

\subsection{Hypothesis}

Like all societies world over, Kashmiri society too has transformed in every aspect and eventually evolved over time. Metamorphically, it has acquired both prospects and as well as flaws in its route to consolidation as a generic society. Tardy marriages in its conception must substantiate the reasons to prevail and exist. And also must logic the virtue in its prospect of being acquired cum accommodative in contemporary Kashmiri society. The reasons and axiomatic ramifications that lead to tardy marriages among educated Muslim Women folk in Kashmir Valley must be ascertained in the light of potential factors that influence psychology of general masses, so that a strategic arduous solution to counter and castigate this imperil that creates distortion and soreness in the social fabric of Kashmir is fetched.

\subsection{Universe and Sample of the Study}

The universe or the population is aggregate of all units, possessing certain specific characteristics of which the sample seeks to draw conclusions. The universe of the study means exact area where from the individuals for the sample are selected. The universe for this study is the Kashmir Valley Indian controlled. The choice of Kashmir Valley as the universe of the study was selected because this area is completely unexplored and no such study has been conducted which provides information regarding the reasons and axiomatic ramifications that lead to tardy marriages among educated Muslim Women folk from social psychology standpoint and secondly, researcher nativeness - personal acquaintance with the place and familiarity with its languages and peoples way of life.

\subsection{The Collection of Data}

Collection of data for the study under reference began with secondary sources. The information gathered from secondary sources provided an in-depth understanding of the historical account of the transformation of Kashmiri society. These sources proved fruitful in building some theoretical assumptions and parameters for the method of inquiry. Before going to the field and actually interviewing people the research work began with a pilot study which starts before the field work. For pilot study, researcher took 50 Kashmiri Muslim educated females from different areas and a focus group to infer the meaning and reasons of tardy marriages as implied. And also to understands the ramifications and aftermaths of tardy marriages in Kashmir valley.

The analysis of the pilot study helped the researcher to form the basis of an outline including the desirable items to be included in the in-depth study of reasons and ramifications of tardy marriages from socio-psychology outlook. On the basis of this pilot study, a sample of 500 individuals was selected accordingly representing all areas of Kashmir Valley and also belonging to all walks of life. The pilot test was carried for the questionnaire and minor modifications to reduce the saturation effect were undertaken. Thereafter, field work was carried out by the researcher. A standard questionnaire was designed and administered to 500 potential respondents and was used as a tool for data collection. Data was analyzed to fetch information. Finally the research findings were drafted in detail, and presented in the form as a report/paper. Thus, the information collected from primary and secondary sources about reasons and axiomatic ramifications that lead to tardy marriages among educated Muslim Women folk in Kashmir were put in pre-determined theoretical framework which became the basis of our observation in the findings. These findings were analyzed in the context of socio-psychological framework and conclusion were drawn in relation to the findings on which hypothesis were based. Researcher was also conscious about the bias which generally creeps in the study framework. Hence, the scientific method was incorporated and such problems were solved and the desired goals were achieved.

\section{Result and Discussion}

What seems to be a trivial issue regarding the generalization of "appropriate age" to get married in a particular society at particular instance is actually a matter of absolute contention for all stakeholders? In real practice it is 
an extreme state of affairs to arrive at a conclusion as to what age is most suitable for opposite genders in a particular population or society to enter into wedlock. The word "appropriateness" signals different meaning, carries different connotation and criteria to different mindsets and institutions. As per government legislation in Kashmir, the minimum age for a female to get married is 18 and for male is 21 years. The factors taken into consideration by legislators in deciding minimum age limit is predominantly influenced by physical and mental health of the bridge and groom. The appropriateness of age to get married greatly varies from perception to perception. Primarily different viewpoints are carried by different set of people across different regions, races, religions, families, classes, castes, ethnicity etc. Even individuals belonging to same set sometimes carry different notions.

Some people are also in favour of introducing the maximum age limit to enter into wedlock or thence to set a penalty for offenders if not adhering to this proposed social standard. This school of thought perceives the society as a custodian of the resources possessed by an individual in personal capacity e.g. vigor, youth, health, beauty and other associated qualifications etc. Such a class believes that these valuable assets must be utilized by an individual at its own will but within a time frame as proposed by the social system, else things sooner or later fade leaving the vacuum or dearth of such unquantifiable entities in the society. They actually feel that it is the society who offers its individuals resources like security, education, values, norms, belief, discipline, morals etc. by virtue of which they grow and shape themselves to what they are today. To substantiate this argument, they put a parable in order to make things clear by saying if it is justified that an individual refuses to pay road taxes, yet is interested in running a car on the road. One needs to pay back genuinely to the society as one owes everything to it. Man is a social animal and cannot live in isolation. Ones legitimate expectations to get married at an appropriate age cannot be deliberately ignored by the opposite gender in question. Since opposite genders are interdependent in terms of marriage, this genuinely implies and warrants that age as a factor should be legislated both in its lower and upper limits as well. For sake of an argument, on one hand, any individual who differs in opinion or doesn't adhere to the law of the land in terms of minimum age limits to get married, such an individual is termed as an offender and is penalized by the law but on the other hand if an individual is not interested in marrying despite possessing all resource quantifiable or unquantifiable is let free without being questioned or censured. How far can this be justified in letting an entity go free just for the sake of an excuse that he or she is still in search of excellence in terms of counterpart despite the fact that he or she has crossed the appropriate age to get married? Factually this seems to be a double standard. Allegedly, those who are willing but hindered or not allowed to get married at their appropriate ages indulge in activities like pornography, masturbation, eve teasing, molestation, illegal sex, rape, drinking, drugs, vulgarism, terrorism etc. There is no reservation twined as far as gender in concerned in this observation.

In the essence of races, there is no universality in the "appropriateness of age" to enter into wedlock. Arabs and Hispanic e.g. are well built races from physiology standpoint. Factors like genes, calories intake, solace, peace of mind, avenues of recreation and parental care makes an Arab female student of 5th grade look like a full grown in terms of physique and apparently ready for entering into a wedlock. Similarly comparing regions around the globe, then there is no cohesiveness e.g. an average American male student of $6^{\text {th }}$ grade far exceeds the level of maturity to a graduate student of any Indian University. On an average an American juvenile knows and rather is practically aware of what crushes, orgasm, pool dance, pub, happy hours and marijuana etc. means. In arriving at the conclusion regarding the "appropriateness of age" in the Kashmir context, the situation becomes more complex because the society is much diversified with lot of ethnicities, religions, culture, races, sects, ideologies and sub groups etc. Likewise, from families' consideration, few are very open and liberal in its constructs and the depiction of it in terms of sense of maturity could be drawn at much early stages in females when compared to other families. Similarly, in some families, the fundamental stringent religious attitude of elders also plays an important role in fixing the appropriateness of age for females to get married. As per this ideology, the early marriage the better it is. It is evident that in case the "appropriateness of age" is arrived at, then those marriages that are deliberately delayed can easily be categorized or referred to as tardy marriages. As a matter of fact, a clear introspection is required in Kashmir Valley as to what standardizes the age in general as 'most suitable' and 'appropriate' for marriages.

As far as Muslim educated women folk of Kashmir Valley are concerned, their perception varies greatly in this regard. There are multiple set of factors influencing their psychologies and when these are refined to complexities when studied in quantum, they exhibit geometric progression making it nearly impossible to infer their roles and cross effects in terms of abstract sociology. When asked, about the age, they wishes to get married and by also keeping factors of influence into consideration like education, health \& stamina, level of maturity, family establishment, adjustability among in-laws, raising children, effects of social evils and prevailing security 
situations in the Kashmir Valley, the response consolidated is pretty much in a concrete range. $30.39 \%$ females would like to get married in the age range of $20-25$ years, $65.68 \%$ would like the get married in the age range of 25-30 years and 3.92\% would likes to get married in the age range of 30-35 years. No one wishes to get married before 20 or after 35 years of age respectively. Factually these are the true representation of the aspirations of female folk to get married, then who and what are the hindering agents that shape this normality into abnormality. That is a big question which needs to be pondered upon and thoroughly investigated for answers. The three ranges and their associated percentages of representation fetch us the appropriate age for Kashmiri educated Muslim

females to enter into wedlock. This without any ambiguity consolidates the "appropriateness of age" in conformity with associated percentage population. Beyond this age range coupled with its associated population, any marriage that shifts from normal would be categorized as tardy one. Connoting this perspective, the factual situation in Kashmir Valley is very much grim. If this inferred information in current study is taken as a standard, then nearly all marriages happening in Kashmir Valley can be termed as late or delayed ones. Arriving at three age ranges and their mapping with percentage populations leads into analysis phase of the social-psychology factors that basically yield to such a result in exhibit.

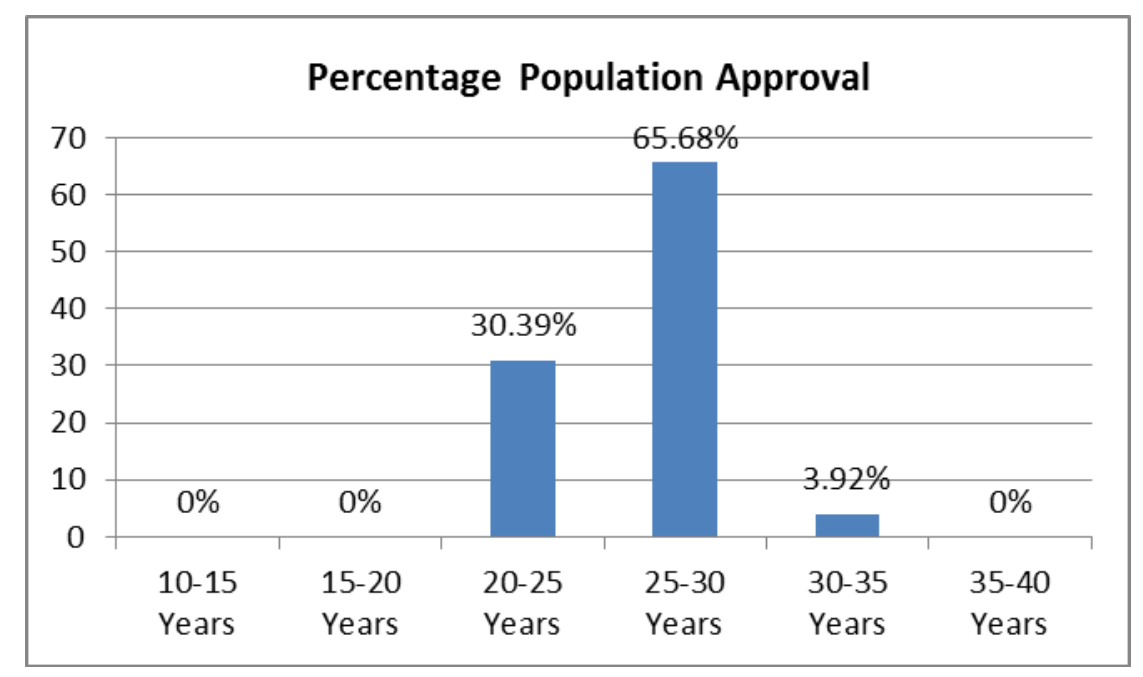

Figure 1. Appropriate Age (range) to enter into wedlock \& Percentage Population Approval as per Educated Muslim Women folk of Kashmir

It is observed that the educated Muslim female folk in Kashmir are more conspicuous, aware, determined and upto date in current knowledge scenarios. What make Kashmiri women unique is the adroitness they preserve by virtue of the most fertile minds and also the shyness they exhibit in all domains of their instincts. In Indian educational setup, any graduate passout in any stream normally implies that the candidate has crossed 21 or 22 years of age. In Kashmir context, the minimum qualification required to be termed as an educated fellow is graduation. That is why in "suitability age for marriage" 10-15 and 15-20 are carrying zero representation from the population. Preferable all Kashmiri women wish to complete graduation at least and then only their parents start looking for a match for them. The general perception among Kashmiri females is that, it becomes nearly impossible to further education after marriage because their responsibilities after marriage increase multi-folds and in multi-dimensions. Whatever qualification one has to acquire has to be prior to marriage in any case. Kashmiri society as a whole is very sensitive and emotionally very delicate; baring few exceptions like the terminally ailing grandparents or parents who wish to see their wards get married in their life time, in no other circumstance would Kashmiri women marry before her graduation. It is inferred from the analysis of data that for $30.39 \%$ of Muslim educated female population in Kashmir, tardy marriage age begins immediately after passing 25 th birthday, similarly for $65.68 \%$ population tardy marriage age begins immediately after crossing 30 years of age and for $3.92 \%$ population it begins immediately after crossing 35 years of age respectively. 
On examining the spectrum that upholds the "appropriateness of age" to tie a knot in the age range of 20-25, as approved by $30.39 \%$ educated Muslim women folk of Kashmir; this segment in focus exhibits different set of psychologies behind the offered consent. Families belonging to elite or well-off class in terms of wealth accumulated, political power, business establishments', bureaucracy etc their women folk are least bothered about the financial implications or post considerations of married life. What matters for them the most is the pleasure and enjoyment of life without any kind of exertion and the legacy of eliteness to be carried and continued forward from one generation to other. For this strata of women (would be brides), the educational pursuit simply means carrying a status symbol and majority of them even join universities on capitation / payment seats. They preferably opt to study only those courses that are not so cumbersome to pass like non-science streams. Usually such entities join universities, just for the sake of finding a match for themselves. Parents often offer leniency to their wards in this chase and are much aware of this as an acceptable norm within family orientation.

On the other hand, those families belonging to the lower middle class in terms of stratification based on avenues, resources, wealth, social capital etc they generally live in a small world and live factually without keeping high expectations of it. They are least sensitive to social implications surrounding them. When it comes to social standardization, their exposure and level of maturity is moderate. Their perception simply is to marry and lead a normal life in their own context. Their elders and well wishers consider this worth saying: "when there is a ready customer for milk, why to wait and turn it to curd and then look for customer?" Such families see their women folk hardworking and competing in all spheres of life, keeping into consideration good sense of occasion and level they belong to in social stratification. More often they are aware of the fact, as to how much and to what extent their family especially parents can afford to support them in the marriage endeavors. In short they belong to a group that struggles to exist without remorse. In short, by upholding the "appropriateness of age" to tie a knot in the age range of 20-25, their psychologies accept the reality they live in and the challenges they face ahead in life. Other families falling in this range are hardliners or too fundamental in religious aspect. Their women know in advance the fate in this essence and are readying themselves for this scenario much before. Often, it is seen that only hurdle in tying the knot in this age range are the financial ones, that is usually overcome by fetching loans either banks or near or dear ones.

Those upholding the "appropriateness of age" to tie a knot in the age range of $25-30$, as approved by $65.68 \%$ educated Muslim women folk of Kashmir; this segment usually belongs to either average middle class or upper middle class. The women folk belonging to these strata are working class, especially government teachers, bank employees and engineers by profession. They begin their careers from base level and immediately on getting a permanent job, they prefer to settle. Only matter of concern in these strata is the place number in the chronological order to get married as far as siblings are concerned. It is taken otherwise in the family setup as well as in Kashmiri society, if any of the sibling moves out of the turn to tie a knot. In such a case other siblings waiting in the queue face lot of hindrances in getting a nice prospect there on. As far as, the other group is concerned that upholds the "appropriateness of age" to tie a knot in the age range of 30-35, as approved by a meager $3.92 \%$ of educated Muslim women folk of Kashmir; this segment is more of a practical oriented in nature and can be categorized as risk averters. This lot wishes not to be dependent on their spouse at least in monitory perspective. They actually have a deep understanding of true realities of society and they know rather very well how far they have to struggle from all standpoints of life. Majority of the females in this strata are research scholars and specialized doctors by profession and their pursuit simply implies a long way to go as far as marriage is concerned. This group carried high maturity level and preserve lot of patience. Their orientation in terms of family members is often high with sibling count ranges from 4-7.

This is how common Muslim educated Kashmiri females perceive things related to appropriateness of age for marriage to be like. If such is the case, then where lays the actual problem and what are the psychologies that are carried by befuddled society that hinder this normalcy and become the base for calling the marriages as tardy. On the basis of classification based on fervent social-psychology, there are twenty (20) factors and associated philosophies that prevail in contemporary Kashmiri society hindering the normal pace and process to tie the knot at appropriate age, thereby creating stymies at every point in its permutations and combinations. These factors can actually be summarized as the attributes pertaining to the groom that play an important role in the selection process for a match. They are tabulates and connoted with tags (A-T): 
Table 1. Description of Attributes/Criterias \& associated Tags (A-T) pertaining to the Groom that plays an important role in the selection process for a match in Kashmiri Society.

\begin{tabular}{ll}
\hline Criteria & Description \\
\hline A & Qualification e.g. (10+2/Graduate/PG/PhD- BE/MBBS/B.Sc/BA/MA/MBA/MCA) etc. \\
B & Schooling e.g. (Convent/Private/Government School)etc. \\
C & Profession e.g.(Doctor/Engineer/Bank Manager/KAS/Teacher/Lecturer) etc \\
D & Age e.g.(30+/ 35-) etc. \\
E & Family Orientation e.g.(nuclear or joint family \& service class or business class family) etc. \\
F & Caste/Dynasty: Upper Caste: Thakur, Shahmiri Lower Caste: Sheikh, Dandroo, Siraj etc. \\
G & Family Strength - Groom's number of Brothers and Sisters \\
H & Personality \& Lifestyle e.g. (height, complexion, health, beard, dressing Sense, puffing) etc \\
I & Employment Status e.g. (Government Employee/Private Job/Owning Business) etc. \\
J & Employment Nature e.g.(Permanent/ Contractual/Adhoc/Daily Wage) etc. \\
K & Job Location: e.g. (within State/Country/Foreign) etc. \\
L & Prosperity Status: e.g.(Established /Settled (Income/Wealth) etc. \\
M & State Subject: e.g. (Local/Non-Local -Kashmiri/ Non-Kashmiri/NRK) etc. \\
N & Ancestral and Current Resident: e.g. (Actually belonging to City or Village) \\
O & Religious Sect: e.g. (Shia/Sunni and Hanfi/Shafi etc.) \\
P & Religious Influence: e.g.(Moderate/Liberal/Fundamental or Hardliner) etc. \\
Q & Bridal Money Offering e.g. (Offerability of bridal money -Mahr) \\
R & Residence and Location: e.g. (Bunglow, villa, downtown/civil lines/ mohalla/colony) etc. \\
S & Spouse's Working Status e.g. (If allowing spouse to do job after marriage or not) etc. \\
T & Political Views and Background e.g. (Pakistani/Independence/Ex-militant) etc. \\
\hline &
\end{tabular}

In order to understand influence and the impact of each criteria in the decision making process, it is imperative to understand the psychologies behind each individual factor as well as their interdependence. Each factor associated with the psychology actually conduces to the reason/s those eventually lead to tardy marriages in Kashmir Valley. Expectations to satisfy each and every factor in its endeavor is too much time consuming in real practice and since Kashmiri women folk are too choosy in all respects, this is the prime reason that their marriages get delayed to an extent that their marriages are considered as tardy and in true sense such marriages carry serious ramifications.

Beginning with qualification of groom, there is an outlook in Kashmiri society that qualifications are considered directly proportional to the age of the groom. More the qualification means acknowledgement of more age relaxation. These are solicited and duly granted in the selection process of the groom. Higher professional degrees imply utilization of more resource inputs in life and hence proportional higher value of the groom in the marriage market. Sometimes, groom's family remains in an anticipation of more dowries from bride's parents and often indirectly demanded so on this pretext. More often, they weigh the prospect in purely monetary terms and those families having more daughters are given less preference. More the sisters of the bride mean fewer dowries to be fetched and fewer/lesser shares in their property as well. Kashmiri society is considered as extremely 'mean' in this regard. On the other hand, parents always have an expectation to fetch highly qualified match for their daughter but at the same time have to tradeoff this factor with that of the age of the groom plus to consider the dowry aspect as well. It is true but very rare that caste as a factor at times is compromised with that of higher qualification of groom. In addition, to this, natural competition between siblings to fetch the best match in comparison to others in the family also hinders the normal course of action, thus leading to supernormal time consumption in the selection of groom. Out of twenty (20) factors (A-T) as listed above, $16 \%$ of the educated Muslim female folk of Kashmir give 'age consideration' as the criteria their first priority. 


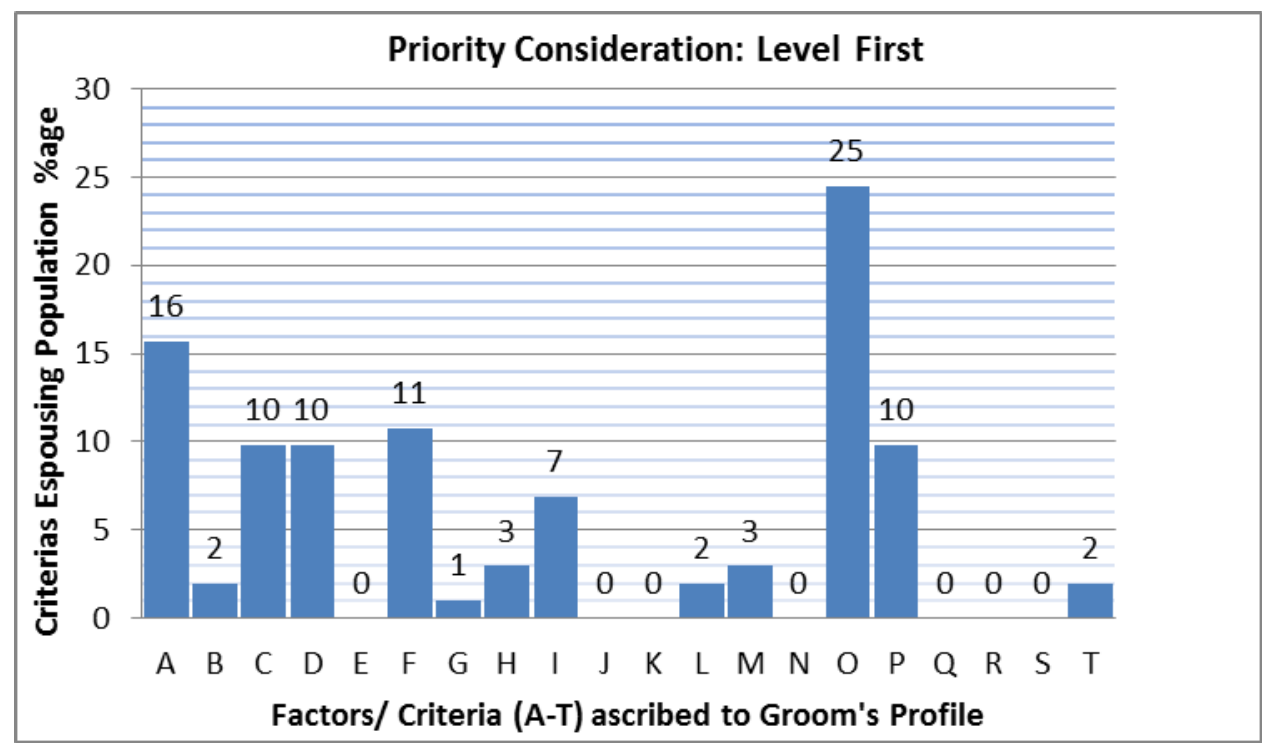

Figure 2. Criteria considerations (A-T) and espousing population percentage as per Educated Muslim Women folk of Kashmir Valley in their first Priority Option.

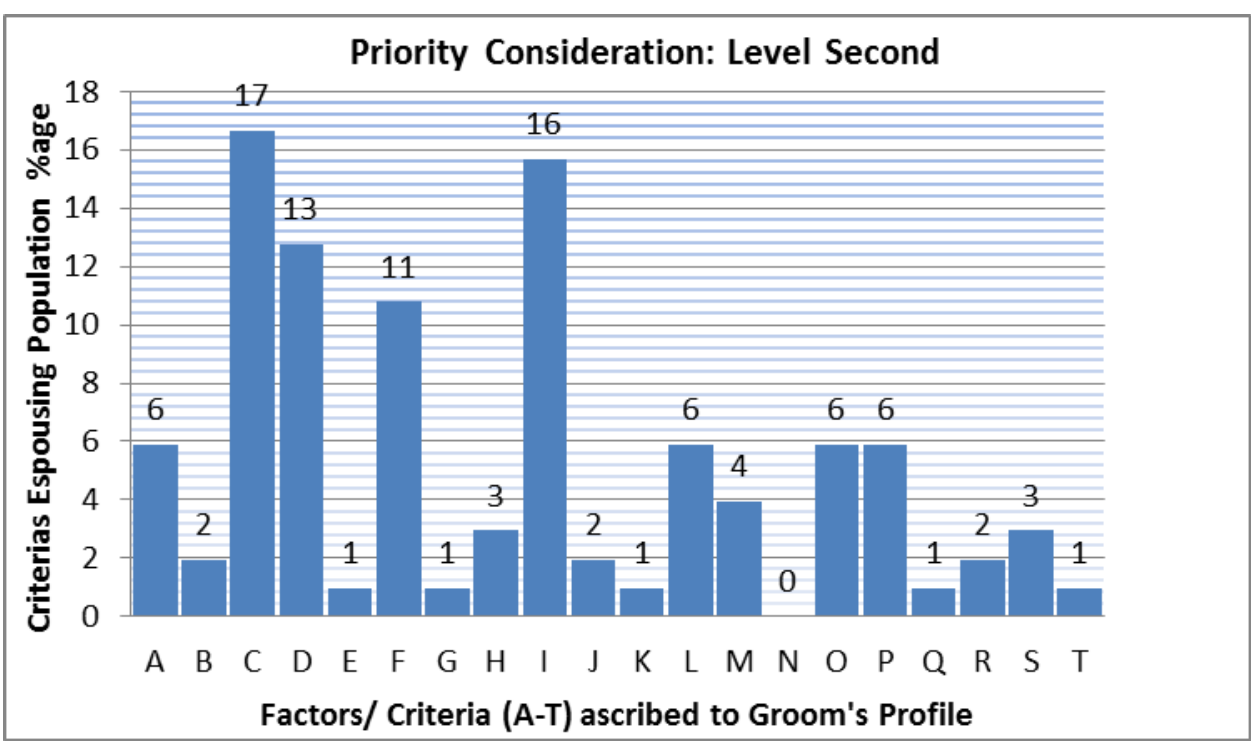

Figure 3. Criteria considerations (A-T) and espousing population percentage as per Educated Muslim Women folk of Kashmir Valley in their second Priority Option. 


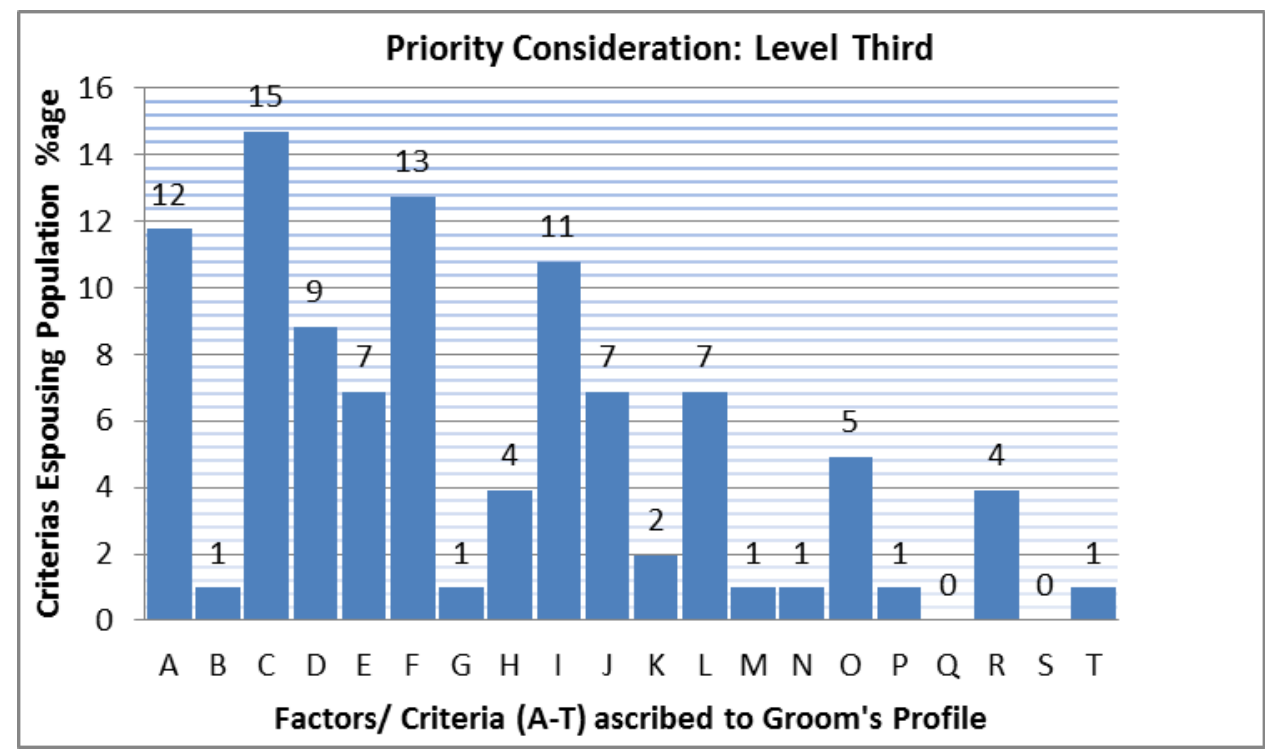

Figure 4. Criteria considerations (A-T) and espousing population percentage as per Educated Muslim Women folk of Kashmir Valley in their third Priority Option.

Schooling, as criteria for the selection of groom plays a very important role in Kashmir society. Convent schooling of the groom implies belonging to a descent and well-off family and vice versa. Convent schooling of groom also implies that the prospect is liberal and moderate in etiquettes plus having a broader mind set. It is also reflective of the personality traits like good spoken English, cultured, good dressing essence, frankness, openness and presentable etc. It is a trend in Kashmiri society that men most often seek alliance from counterparts having undergone convent schooling only, that too within the premises of the state. Any prospect, keeping convent schooling from outside state is doubted of moral corruption and illicit pre-marital affairs. Any prospect, irrespective of gender having government schooling is considered as inferior from all standpoints. Schooling as criteria is considered as litmus test to ascertain all goodies that the groom or its family can offer to the bride. As a matter of fact, families prioritize this factor so as to conclude, that all the rest in a package is worth considering for the selection of the groom. To conclude, search for a prospect having convent schooling in addition to other factors or criterias make it a tedious job for parents to fetch a suitable match, there by leading to paranormal systematics in marriage psychology among Kashmiris. A good profession as criteria superimposes the schooling criterion that is the reason only $2 \%$ of the educated Muslim female folk of Kashmir reckon 'schooling' as the criteria their first priority. It implies that the schooling doesn't matter much in quantification when the prospect is considered keeping good profession.

Profession of the groom is considered and often referred to as an impression of the index of the mind. In Kashmir context per se social-psychology \& usually perception not necessarily true is all contexts, e.g. practicing medicine was considered as noble, but not so now-a-days. Doctors are doubted to keep relations with nurses and their night shifts in the hospitals add fuel to this fury. Still doctors are considered as sober and highly respected, like wise civil, electrical or mechanical engineers are considered rough, pugnacious and thieves, teachers as considered dry, crooked, misers and mind frying, lawyers as liars and corrupt, bankers as interest earners, businessmen lacking basic etiquettes and discipline, policemen least bothered about family and often on stringent duty schedules and stationed away from their families. In the situation of counter insurgency, police and para-military personnel often fetches least response to marriage proposals, because of risk involved in security operations etc. Knowing all this and keeping such mindsets, yet do people marry? Selection of the groom having a good profession matters much in Kashmiri society. In majority of the cases, men and women like to tie the knot with those keeping similar profession; unlike engineers they usually seek alliance from prospects holding teaching profession. Few set of psychologies, seek alliance from qualified but wish to have them as home makers only. Corollary to this fact, the female folk of Kashmir thinks that a person who is much adamant in finding his would be wife to be as home makers only, implies absolute dependency, dictation of husbands and his complete grip on all family domains thereby meaning a limited degree of freedom to the 
females in such an environment. Out of the factors (A-T), $10 \%$ of the educated Muslim female folk of Kashmir give 'profession' as the criteria their first priority. Keeping others factors into consideration as well, on an average this factor maintains representation ratio to $17 \%$ and $15 \%$ in their second and third priority levels respectively. In these perspectives and scenarios, things overall become difficult to manage and time consuming for all stake holders that this criteria consumes ample time and energy to arrive at the conclusion and ultimately delay the decision to select the match.

Age of the groom at the time of seeking alliance for marriage and as criteria for selection is commonly practiced in Kashmiri society. More age of groom means less potential responses to marriage proposals. It is always skeptical to digest the argument or non obvious reasons for not marrying beforehand. Self concluded reasoning could range from doubting groom with health issues, engagements before, pre-marital affair, financial issues, militancy involved or cross borders or behind bars etc. more age means less innocence and high maturity. This also implies likeness of no chemistry between spouses, no excitement, less vigor, no interest in sex enjoyment, boring personality, sometimes referred to as miss

match. Laughable! But at times true in Kashmir context, 21 means too young to shoulder responsibilities and 37 means too old. $10 \%$ of the educated Muslim female folk of Kashmir give 'age' as the criteria their first priority. This scenario is steadily maintained in their second and third priority levels as well. Established fact is that females should be on an average 5-7 years less in age than males at the time of tying the knot. Very rarely is seen a marriage where bride is more in age than a groom. In such case, the groom's friends and relatives usually tease him with a joke or comments - a chap married to 'an aunty'.

Family orientation and family strength of the groom are important factors that are thoroughly investigate by the parents of the bride. Nuclear family is preferred over joint family. As per women folk of Kashmir, joint family means more efforts required to manage family affairs with lot of interference on all aspects especially from elders. In such situations, it is understood, that husbands are usually carried away by family norms, protocols and huge family expectations. In this apparatus, husbands are caught up in the messy situation like between the devil and the deep sea. Female folk perceive joint families as a torment with no spare time for self and least savings of husband's income. Usually the earnings and family expenditures are shared in a pool fashion. The situations are seen escalating in families, wherein one daughter-in-law is a home maker and the other is a working professional. Stiff competition for supremacy and space cum degree of independence is often witnessed making family orientation difficult to sustain, thereby eventually breaking up to the nuclear ones. At the inception, no parents wish to put their beloved daughter into an awkward situation. As such they try to seek alliance only from potential families that are nuclear in orientation. They prefer to put their daughters in no conflict zone, for this they have to search a suitable prospect and such prospect families are very rare to be found in Kashmir. In addition to this prevailing psychology, a portion of the population perceive service class families are simple and easy going where as business class families as crooks and selfish. This is also the reason that these two types of families prefer not to seek alliance from each other. The women folk foresee the adjustability problems if this bitter truth cum reality is not accepted and adhered to. Somehow such a notion fades drastically, when it comes to other criterias like, employee status, caste, job location etc. Family strength is also a criteria worth for consideration in terms of number of sister and brothers a groom possesses. If sisters are elder and married, then the prospect for marriage alliance is taken further for consideration. If the brothers are more in number and live jointly in an ancestral house, the prospect is tagged with red flag. It is so because; in future, the property has to be divided between siblings, implying more the share holders less the individual apportion. In Kashmiri society, these things are pre-calculated before entering into any marriage alliance with any family. Considering these two factors or criterias, less or nearly negligible population considers them as important, usually these factors are suppressed by other influential factors of importance.

Social stratification is prevalent in all societies world over. But in Kashmir context, caste consideration is one of the major polemic factors leading to tardy marriages. Nearly all families in Kashmir Valley believe in caste system. People who belonged to royal and elite in Hindu religion, but later reverted to Islam consider themselves as superior and imperial e.g. Thakur, Pundits etc. Similarly those families whose descendents came to Kashmir as missionaries of Islamic faith still consider themselves as superior and pious in terms of lineage e.g. Syeds, Siddiquis etc. There is always a tug of war between them in order to prove and claim supremacy over each other. As far as marriages are considered, the proposals are out rightly rejected by each other on this pretext, and also with those whom they claim to be born inferior in caste e.g. Dandroo, Sheikh etc. This in reality is a pathetic prevailing situation in Kashmir valley and a true cause for marriages to get delayed beyond limits. In order to get rid of this menace, people have started adopting other castes from lower to upper ones e.g. from Rather to Rangreez, Panzoo to Shah, Ganai to Geeri etc. Matching other referential factors, when it comes to caste 
consideration, there is philosophy of no compromise. Seeking alliance in such testing and taxing scenarios, elders in a family are hell bent and adamant to settle down for a matching caste. When it comes to caste consideration, piousness, sincerity, religiousness, education, and prosperity level of groom under consideration are for granting factors. Out of the factors (A-T), $11 \%$ of the educated Muslim female folk of Kashmir give 'caste considerations' their first priority. It is really shameful to notice this behavior from educated class in Kashmiri society. Such scenarios are understood to continue in their second and third generations as there is no initiative taken from any corner to rectify or correction the social system.

Kashmir Valley is not only famous for its beautiful natural landscapes but also for the beauty deeply embedded in women folk. Kashmir women are generally healthy, modest, with fair complexions and carry lot of shyness within. This naturally arouses expectations in them too to fetch a matching life associates with similar attributes. A well built, fair complexion, tall, not bald, over all handsome personality is all that is expected by a female to be associated with throughout her life. At times, a bus driver far exceeds in personality than a professor of the university. It is all about the personality grooming and consciousness depicted by virtue of self maintenance, a bob hair cut with nice dressing essence seems naturally inculcated. It is noticed that people sub-consciously wear dull or faint colored cloths as per their choice in the dress codes; this seems to be an indicator of stress level carried because of the ongoing turmoil in conflict zone viz. Kashmir. Also because of the Sufi-cultural influence prevailing in Kashmir Valley, people generally prefer cloths (color combinations) not depicting pomp and show. Men with full grown beards are considered "Taliban" and are least preferred as a match in terms of marriage prospects. If such a person is working in a government sector, then such a prospect is considered to be worthless, because such personality would be desisting from taking bribes; generally considered a legitimate right for a government employee in a state with high indexing in corruption. The fact of the matter in reality is opposite to this general notion. Often it is said that a person having a full grown beard carries a devil within it. Out of the factors (A-T), 3\% of the educated Muslim female folk of Kashmir give 'personality and life style' worth consideration as per their first priority. Keeping others factors into consideration as well, on an average this factor is maintained at $3 \%$ and $4 \%$ in their second and third priority levels respectively.

Employment status, employment nature and job location are important factors under scrutiny when it comes to match making in Kashmiri Society. Men with government jobs even with meager salaried in comparison to prospects having private jobs in a corporate world are preferred. Even over business men having millions of worth at disposal. It is so because; government jobs carry constant monetary flow cum guarantee and integral security as well. Government jobs are also lucrative in essence as they carry health insurance, pension benefits, and service completion benefits etc. Nature of employment as criteria is also taken into consideration for match making. Adhocs or daily wagers are considered better than a contractual employees, because adhocs and daily wagers as per state government service rules have chances to become permanent employees, not so in case of contractual employees. That is why preference is given to candidates with government jobs in hand. Kashmiri women folk are emotionally and socially well connected; by and large they prefer to be in the valley alone after marriage. It is so, because they love to be in feasible environment of solace that is only possible when they live with their near and dear ones. Thus it becomes incumbent upon parents and elders to find a suitable match in local vicinity for their daughters so that they could live peacefully in their natural surroundings, socially as well as geographically. The matter of contention arises in a family when, either of the two i.e. husband or wife works out of station or outside Kashmir valley. In addition to it, the confusion arises when in such circumstances both (husband and wife) are working and ones job location status is transferable and others not. Least priority is given to matches doing jobs abroad especially in Saudi or gulf region. Numerous cases have been in the news where in the grooms were already married outside state or country and even some of them were having children, yet there parents were looking for the match for them in Kashmir valley. Parents of brides are generally skeptical about such prospects. It is also a consideration of the general masses in Kashmir Valley that who so ever marries outside the state either by bringing or giving daughter in marriages are considered and termed as renegades because they are perceived to have contaminated the pure gene pool of Kashmiris in terms of progeny they would carry forward. Out of the factors (A-T), 7\% of the educated Muslim female folk of Kashmir perceive 'employment statuses as the criteria worth consideration. Meager but due considerations are also given to nature of employment and groom's job location by the psychological constructs of educated Muslim female folk of Kashmir.

Prosperity level and life style of groom are also considered as the factors with much importance in match making in Kashmir Valley. Men having personal properties like home, car, bank balance or side businesses fetch more responses in marriage proposals than others. If the candidate is the lone son of the parents, such as prospect carries tremendous priority and are chased from the very beginning even from their childhood. Families seek 
alliance for their daughters from those potential prospects who have fewer siblings especially brothers. They think that their daughter's life shall become tough and rigorous if the couple has to construct a new house in the future in order to stand as a nuclear family. That is why they prefer a candidate who is already settled in these parameters. Outside Kashmir, majority of Muslim families are in a constant pursuit to marry a bride from Kashmir, it has now-a-days become a status symbol for them. Kashmiri women are beautiful, bold, innocent and intelligent with lot of shyness preserved within are looked upon as a prospect. These are the ingredients that a groom is actually looking for in a prospect to settle with.

Apart from this, Kashmir society keeps a huge gulf and is seriously divided between urban and rural populations. Kashmiri villagers even if they have shifted and settled in city decades ago consider basic city dwellers as their rivals. They consider city residents as snatchers of every shareable resource and also carry prejudice for seeing them in a well off condition. Basic city residents find people belonging to rural areas full of inferiority complex. In contrast, people belonging to rural areas find city dwellers full of false ego on the pretext of being residents of city, even if they belong to down town localities where one could still find shit flowing in the surface of drainage channels in their mini lanes. Nearly $72.62 \%$ of the valley's population resides in rural areas and the rest $27.37 \%$ in urban areas. Village dwellers are thought to be greedy and cunning, in such circumstance establishing relation for marriage alliance is out of question. It is a metaphor often referred to in Kashmir, that "Kashmiri Villager has defeated the devil as well". If relation is established, even if it so happens by chance or under any compulsion e.g. love marriage, it is understood that for family belonging to village, this relation has opened avenues for them to a have a depot in the city central with free boarding and lodging facilities that too with leisures under relationship protocols. This prevailing psychology infers that baring exceptions, nearly $72.62 \%$ of rural populations desist in making any alliance for marriage relation with that of $27.37 \%$ of urban population.

Another issue with Kashmiri society is the divide based on the religious sects and in tandem with the religious influences. Deep divide in society is noticed on these accounts. Astonishing to know, in spite of the fact that Muslim believe in one God, one final messenger, one divine book, yet they are divided in sects and sub sects. Shias and Sunnis are invaginatively poles apart from ideology standpoint and are at times even referred to as non-muslims by each other. Rarely any marriages are seen between Shia and Sunni sects. Some notorious and rogue Sunni male youths are often found indulged in or looking for chances and opportunities to flirt with Shia ladies as they are thought to be very beautiful and more attractive in personality. They never intend to give the relationship a serious thought because of the reservations and opposition from their respective families. Those Shia ladies indulged in premarital affairs know for sure that eventually, they have to marry Shia grooms only. Their flirting remains a secret and confined to other sect. Such deep secrets never cross over to other side, thereby maintaining least possibility of exposure that would bring them a bad name. In addition to the Shia and Sunni divide, Kashmir valley witnesses another set of sub-divides i.e. Hanfi, Shafi, Hambli and Maliki mazhabs or factions. It is grave situation in Kashmir valley as far as religious factions are concerned. Even the mosques are specifically meant for specific sects or mazhabs. Religious influence is also a factor that is taken into account when a grooms profile is securitized. Moderate to fundamental and liberal to hardliner is gauged in scales. This influence is understood to coincide with the attitude of the groom in future orientation, e.g. would he be asking the spouse to maintain a complete veil or just a Hijab. This is equally reflective to the degree of independence and freedom limits in other aspects of house hold and decision making that the bride would be enjoying after marriage. As a family one has to decide before hand, as to what type and to which level she can tolerate the dictate or the degree that she can be accommodative to in this regard. In addition to it as criteria to hold into account, it is also ascertained and information is sort on this account too for any conditions preset before match making and is communicated to the bride in advance. Also if she would be allowed to continue with the job in post married life. Such conditions are deliberated upon and sorted out before entering into any relation leading to the marriage. The facts revealing here are very astonishing. 25\% of the educated Muslim female folk of Kashmir perceive 'religious sects' as the criteria worth consideration before initiating any match making process. This means $25 \%$ of educated Muslim female population in Kashmir in their prime priority search for information pertaining to this aspect before proceeding to other criterias.

The quantum of bridal money (mehr) offered at the time of Nikah is of moderate significance in Kashmiri society, but at times it becomes a matter of issue and confrontation for both parties in consideration. If the deal after due bargain is not arrived at, then the groom is asked to offer the same amount as his sister or paternal aunt has received on their marriages. In true terms, since it is a matter of counter security, the bridal amount either in gold or cash expected to be received depends upon and is quite often directly proportional to the dowry the bride takes along with. It hardly is related to the beauty, looks and health of bride, neither it depends on the qualification and profession of bride nor on the aspect of age of the bride. Matter of actual concern is that the 
females in Kashmir Valley hardly receive this amount in hand. Either it remains written in documents alone or in the form of gold or jewelry. She is never allowed to convert that into cash and spend it on herself. Even if the amount is fixed at the time of nikah (marriage), she is too shy to ask that amount from her husband. Rather she prefers to keep ornaments of gold (if any) in her own custody and if the husband proves to be good and trust worthy, she keeps it at his disposal but only grants it as a loan to him for any time duration. Sometimes in rare cases, she is forced by her in-laws to utilize that for their well being. More often she never intends to use it for herself, instead keeps it reserved for her children.

In Kashmiri society, factors such as groom's residential status and the location of it play an important role in the selection process of match making. If it is an apartment, or flat, or villa in open and the number of floors in it, the gardens if any, old or new construction etc all these statistics are thoroughly checked and cross verified. The true ownership of the acclaimed property is also ascertained. Besides this the location of residence is also taken into account. If the residence is located in the downtown, mohallas with narrow lanes etc, the prospect is given less consideration and if the residence is in civil lines or in posh colonies etc. this automatically imply quality of standard of living and due investments on it. Such criteria as perceived are considered directly proportional to the well being and the status quo maintained by the prospect, true for both men and women about to enter into social- legal relationship called wedlock.

As far as the groom's holding of political viewpoints are concerned, they are rigorously verified if not directly. In Kashmir context, viewpoints of the groom in this aspect carry significant implications. It actually helps in predicting the ideology that the groom carries and it is also presumed to be directly related and equally proportional to the level of fundamentalism and extremism he could pursue in future. It is also essential for the bride's parents to check the background of the prospect. E.g. ex-militants or active ones fetch no response at all in seeking alliance for marriage, if it so happens, then definitely this type of information is deliberately concealed and as such often leads to a controversy and confusion at later stages.

Keeping all the factors \& criterias (A-T) into consideration the question arises as to who among the stakeholders is/ are involved or have a strong say or without whose approval things can't move forward in the decision making process for the selection of a match for a female in Kashmir Valley. On quantifying the influences exercised in the decision making process in the selection of a groom, $61 \%$ of power, authority and control vests with the parents of the bride particularly in father. $8 \%$ of influence vests with siblings provided they are elder to the bride and only on a strict condition that the family they live in is cohesive and not conflict torn. $20 \%$ of the power in terms of the consent is exercised by the women herself. Implying that her influences and viewpoints can be used either way in the line of motivation or de-motivation.

Table 2. Description of Influencing entities (Tag Factors: A-I) and associated percentage of Influence in the selection process of a groom as per the opinion of educated muslim women of Kashmir Valley.

\begin{tabular}{lll}
\hline $\begin{array}{l}\text { Influences } \\
\text { (Factors) }\end{array}$ & Description of Influencing Entities & $\begin{array}{l}\text { Percentage Influence } \\
\text { Decision Making }\end{array}$ \\
\hline Factor: A & Parents & $61 \%$ \\
Factor: B & Siblings (Brothers \& Sisters) & $8 \%$ \\
Factor: C & Self & $20 \%$ \\
Factor: D & Grand Parents/Aunties/Uncles (both maternal or paternal side) & $5 \%$ \\
Factor: E & Neighbors & $0 \%$ \\
Factor: F & Spiritual Personality (Peer Sahib or Maulana Sahib) & $2 \%$ \\
Factor: G & Draw of lots in a Shrine or Mosque & $1 \%$ \\
Factor: H & Friends \& colleagues & $1 \%$ \\
Factor: I & Match Maker & $2 \%$ \\
\hline
\end{tabular}




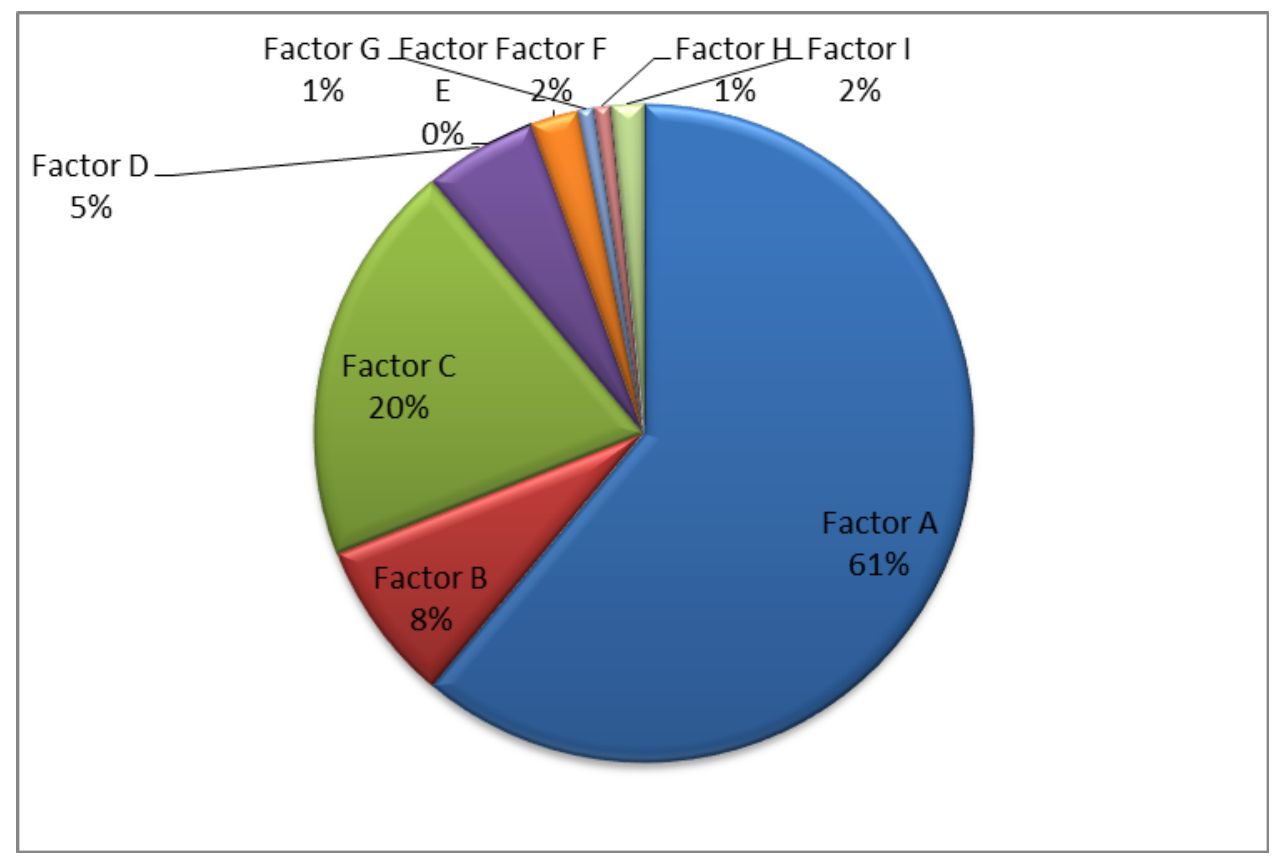

Figure 5. Stakeholders (A-I) reference Tab 2: and percentage of influence exercised in the decision making process for the selection of groom in Kashmir Valley.

Only 5\% influential consent is exercised by grandparents as well. It is because of the knowledge, experience and special expertise in procedures and protocols they carry in these affairs. As far as neighbors are concerned there is negligible influence or no say in this regard as per Kashmiri society. Rather things (profile of prospects under consideration) are kept hidden from neighbors and relatives till they mature and consolidate in terms of engagements. Kashmir being the hub of Sufi saints, large number of families generally believes and often relies on the mystique powers of the spiritual teacher (peers). In order, to know if the relationship is going to be a wonderful and followed by a happy married life, both parties often visit the spiritual gurus in shrines or mosques or at their respective residence, and their consent is sought in terms of blessings. In case there are more than two prospects and equally worthy of consideration, in such cases the spiritual gurus are consulted for decision. At times in standoff situations, draw of lots in the shrines are conducted, so the decision is arrived at as to which prospect is most suited and blissful. Fast and time tested friends and immediate colleagues are at times consulted by the parents of the bride or bride herself especially for the background check related to pre marital affairs or militant connections if any. This when summed up carries $1 \%$ of influence in the overall decision making process. In Kashmir context, professional match makers are considered to be very bad, they fetch a good prospect only if they are paid and promised handsome amount of money. It is they who actually sort the profiles first and refine them and bring them for a particular prospect. If the match maker belongs to a village, he or she always carries a bias in match making. They always try to match the bride's profile belonging to a village with the groom belonging to the city. They always follow their instincts and keep hidden agendas too. Their motivation often is to see a village girl settling in the city thereby establishing for her the base so as to rule the house hold of the city dweller. That is why match makers keep significant impression and overall influence of $2 \%$ in match making scenario. It is worth mentioning, in case the match happens so between a villager and a city dweller, in due course of time the relations acetify to the level that such marriages are considered as mismatches.

\section{Summary and Conclusion}

One could imagine the degree of complexity when all the factors and criterias are considered worth to be included in the decision making process for the selection of groom in match making activity. More so, if each factor or criteria in terms of associated psychologies are permutated and combined for (n) number of potential prospects cross multiplied with (n) number of influencing entities some of whom possessing veto power in final decision, this factually leads all stakeholders to information overloading syndrome. Every criterion is factually ascertained and not an iota of information pertaining to prospect for marriage alliance is left unturned. All 
resources and efforts are synchronized by all stakeholders within and outside the family of the bride so as to be satisfied with all parameters before establishing any relation formally. In contemporary Kashmiri society, on an average it takes 1-5 years to accomplish the search process to settle for a groom and in addition to it, 1-3 years for accomplishment of the project in terms of marriage.

The appropriateness of age to get married greatly varies from perception to perception. Primarily different viewpoints are carried by different set of people across different regions, races, religions, families, classes, castes, ethnicity etc. In Kashmir valley, it is found that $30.39 \%$ of educated Muslim females would like to get married in the age range of $20-25$ years, $65.68 \%$ would like the get married in the age range of $25-30$ years and $3.92 \%$ would likes to get married in the age range of 30-35 years. No one wishes to marry before 20 or after 35 years of their ages respectively. This implies that in a particular society, there is no single age limit set for marriages to be categorized as tardy. In fact, there are multiple age ranges conceived by different sets of population as feasible and most appropriate for marriage and beyond that for every set, different tardy marriage age begins.

On scrutinizing the influencing parameters in the selection process of the groom, family members particularly parents of bride are considered prime responsible for late marriages because they keep on searching for the 'best fit' match keeping necessarily all criterias into considerations, even if it takes years altogether, their endeavor is nonstop. This delay at times goes against the aspirations and wishes of the female herself. Secondly, parents and self (to be bride) keep on putting money together for marriage expenses like jewelry, bridal cloths, marriage function expenses, dowry, gifts etc. Keeping limited earnings and avenues into consideration, this actually takes years to put together. This scenario is noticed peculiarly in middle income group families. More often the females in Kashmir now-a-days prefer to postponement their marriages till they get settled like e.g. Job, position and status then only they think of marrying in order to get a better prospect. This piling and accumulation of resources for marriage actually consumes many years. Likewise majority of match makers are considered awful because, they often don't fetch a good prospect instead they keep demanding money on every home visit, their expectations can't be turned down for obvious reasons. Another reason of tardy marriages is that all neighbors are not considered good enough. Because of the competition, some of them carry prejudice and do not vote or speak well when it comes to the word of mouth that actually matters in the information seeking process for match making. So, overall the process gets delayed. The process of seeking a life associate and its consolidation in terms of marriage is so cumbersome and unenviable that it often leads the women folk of Kashmir into cyclic paranoia. In the anticipation for a happy married life with the tendency of zeroing risk factors, the dingy psycho-evolved system that is dominant is the prime reason that leads the Kashmiri society towards the manifestation of tardy marriages.

To counter and castigate this imperil that creates distortion and soreness in the social fabric of Kashmir, some social scientists are in favour of introducing the maximum age limit to enter into wedlock or thence to set a penalty for offenders if not adhering to this proposed social standard. This school of thought perceives the society as a custodian of the resources possessed by an individual in personal capacity e.g. vigor, youth, health, beauty and other associated qualifications etc. Such a class believes that these valuable assets must be utilized by an individual at its own will but within a time frame as proposed by the social system. Argument is if China could introduce one child policy, so can other societies do for maximum age limit for marriages. This proposal seems ridiculous and inappropriate, but minutely observing it, the logic carries sense. Scientific research is needed to calculate pros and cons if this proposed norm is to be adapted by the society in general.

Despite all the care and due cautions taken in the selection process for match making, 35\% of educated Muslim female population of Kashmir believes that "marriage is a gamble", they conceive that those who make up to a good relationship are winners, blessed and lucky but those who breakup or can't make it to the healthy relationship are losers, destined so and unlucky. In true essence, $62 \%$ of the educated female folk in Kashmir wish to know their spouse before marrying them by virtue of keeping an affair, which could eventually at later stages pave the way for involving their respective families especially parents just for formality and marriage function arrangements. $72 \%$ of educated Muslim female folk of Kashmir perceive university as the best place to look for the match for them; it is so because they wish to present a solution to their parents rather than becoming a core of the problem in seeking an alliance for marriage. As such, 30\% of educated Muslim female folk of Kashmir valley finds social networking sites most useful and handy in finding a good matching profile for them.

The magnanimity and complexity of the problem posed by tardy marriages can be understood by the fact there is no readymade or time bound solution available so far in the society. In fact, tardy marriages are posing a serious threat to the basic institution of the marriage be it in Kashmir Valley or elsewhere. Even if the solution is proposed by the social scientists, it is often difficult to implement the remedies in the social system because the causes of problems are embedded in the deepest levels and constructs of social psychologies and the symptoms 
of it are just revealed as a tip of an iceberg. Scientifically, the solution to this generic problem lies in its problem solving algorithm. Hence, after thorough investigation of the problems posed by tardy marriages, broadly the ramifications can be categorized into two segments; those issues that lead to the actual problem of tardy marriage in pre-marriage scenarios and the other that lead to the problems in post marriage scenarios.

In pre marriage scenario the prime focus of the families is to find the best fit match in very less span of time. All criterias and factors that are considered must be satisfactory to the majority of the influential entities involved in the decision making for the selection of bride and groom. The more one digs deep into details, more the time it takes to settle for a match, similarly more the profiles sought and scrutinized more complex the situation proves to be in the conclusion. The delusion is often sourced from information overloading. At times it pains a lot, when one family OKs a particular prospect after through investigation and verification of all the details, and the other side rejects it on trivial matters. In a particular case in Kashmir, it took complete five years with rigorous workouts by all family members and close relatives to find the suitable match considering all criterias, and then it took three more years for them to enter into wedlock. Marriage ceremony was celebrated with lot of pomp and show. Invitees still remember it. Surprising, it took only four days to break the relation by virtue of a divorce on the pretext that the groom was an impotent. Numerous other similar stories are heard, where the bride was accused of not being a virgin or the bride has a premarital affair etc. This does not necessarily mean that the criterias should not be considered; in fact some considerations must be there but with a liberal and lenient view. In pre marriage scenarios, each passing day in search for the best fit match adds to the complexity and confusion starting from long discussion and debates, cross questioning, miss trust, heated arguments, verbal abuses, communication breakups, anger, stress, anxiety leading to depression and paranoia, superstition and witchcrafts, attitude and behavioral problems, focus shift from match making to property disputes and its divisions, rage and at times suicidal tendency. All these messy situations add to the problem rather than any solution and it stretches the time factor many folds leading to further delay in marriages- tardy marriage.

As far as post marriage scenario in case of tardy marriages as happenings in contemporary Kashmiri society, one finds issue pertaining to health, problems in conceiving, adjustability matters, loss of vigor and vitality, no interest in sex life, extra marital affairs, childless couples, domestic violence, cognitive dissonance leading to divorce, drugs, criminal attitude and murder etc. Imagine the first child of the couple studying in $8^{\text {th }}$ standard and parents superannuate (retiring) from their respective jobs. These are some of the factual things happening in Kashmiri societies as of today because of tardy marriages. Such are the ramifications of late marriages and irony is that the society is sleeping, doing nothing to stop the frenzy epidemic. Knowledge is not power, unless and until applied, so is true in this case. After thorough analysis of the reasons and ramifications of tardy marriages, the following observations is summed up in terms of suggestions to counter and castigate this imperil that creates distortion and soreness in the social fabric of Kashmir. They are as follows:

1. Lot of scientific study and quality research is required to explore further and dig deep into the social constructs of the Kashmiri society, in order fetch practical and result oriented methodologies to pull back the 'marriage age' from extreme end to normal. Strategic research is also required to minimize the ill effects of tardy marriages in the post marriage scenarios.

2. Social stratifications especially caste system needs to be abolished in the socio-psychological parameters. This is only possible by virtue of quality education, good upbringing of children and readying them for next generation. Social scientists need to devise a mechanism to be incorporated in the society in phase manner and not in one go otherwise the social correction cum rectification would be challenged and resisted because of the resistance to change. Urban and rural divide in the society must be gradually narrowed down. This can be done by allocating resources and avenues uniformly. Sect based divide need to be eradicated completely, how? It is a big question mark for all stakeholders of the society who wish and believe in good social fabric.

3. Introduction of the upper age limit to enter into wedlock or thence to set a penalty for offenders if not adhering to this social standard. This legislation needs to be understood in right perspective. Most probably this can't be introduced in democratic setups but rather in a dictatorship.

4. Overhauling social-psychologies and building a strong vibrant knowledge society for the transformation of mindsets of general masses and to create a strong will power to face any eventuality and challenges. This can be achieved by women empowerment in particular.

5. Introduction and setting of penalties and severe punishments for individuals and families who intend to seek dowry and also supernormal bridal money (mehr). Incentives by government and private sector to facilitate marriages at appropriate ages like e.g. increments in salary etc can also help. General salary 
structure needs to be revised, lowest for singles, increased proportionally for those who have parents in a joint family and highest for those who marry and have children as well.

6. Would be grooms must take initiative to go for simple marriage. They need to educated their parents especially their mothers and grandmothers and even disapprove the unhealthy traditions of the society particularly those observes in Kashmiri marriage ceremonies. They can bring a drastic and radical change in the society.

7. Would be brides need to be given ample space in the selection process of the match, rather than to force a decision on them. They must also be allowed to further education at their own will even after their marriages. In-laws need to be supportive and helpful in this regard.

8. Drastic changes in mindset for reduction in the time for the search and selection process in match making need to be undertaken. Rather counting shortcomings in others, society in general and its individuals in particular must introspect as if they would have been the like of those on whom the finger is pointed. It is God who actually created everything and proportioned it, counting and chasing odds in others is nearly to challenging the will and knowledge of God. A true person with correct faith must believe in one God and do the right.

9. Bayt al-Maal - "House of Wealth" need to be properly institutionalized in Kashmir Valley. Focus should be on eradicating the means and source of poverty rather than feeding poor and needy on regular basis. Elite and well-off class need to be encourages for establish more than one family by having more than one wife especially one spouse from poorer or underprivileged background.

\section{References}

Adamopoulos, J., \& Kashima, Y. (1999). Social Psychology and cultural context. London Sage.

Aggarwal, P.C. (1971). Caste, Religion and Power. SRCIR- New Delhi.

A.M. \& G.B. Koolwal. (2005). Two Concepts of Female Empowerment: Some Leads From DHS Data on Women's Status and Reproductive Health. ORC Macro. 15-54.

Agarwala, R. \& S.M. Lynch. (2006). Refining the Measurement of Women's Autonomy: An International Application of a Multi-dimensional Construct. Social Forces, 84, 2077-99. https://doi.org/10.1353/sof.2006.0079

Ajzen, I., \& Madden, T. J. (1986). Prediction of goal-directed Behavior: Attitudes, intentions and perceived behavioral control. Journal of Experimental Social Psychology, 22, 453-474. https://doi.org/10.1016/0022-1031(86)90045-4

Allen, V. L., \& Levine, J. M. (1971). Social support and conformity: The role of independent assessment of $\begin{array}{llllll}\text { reality. Journal of Experimental Social Psychology, } & \text { 7, }\end{array}$ https://doi.org/10.1016/0022-1031(71)90054-0

Amato, P. R. (1983). Helping behavior in urban and rural environments: Field studies based on a taxonomic organization of helping episodes. Journal of Personality and Social Psychology, 45, 571-586. https://doi.org/10.1037/0022-3514.45.3.571

Bochner, S. (1982). The social psychology of cross-cultural relations. In S. Bochner (ed), Cultures in contact: Studies in cross-cultural interaction. Oxford, UK: Pergamon Press. Basu. https://doi.org/10.1016/B978-0-08-025805-8.50008-1

De Munck, V. C. (1996). Love and marriage in a Sri Lankan Muslim community: Toward an evaluation of Dravidian marriage practices. American Ethnologist, 23, 698-716. https://doi.org/10.1525/ae.1996.23.4.02a00020

Dabla BA. (1999). Impact of Conflict Situation on Women and Children in Kashmir. Save Children Fund Report NWI-India.

Dabla BA. (2009). Violence against women in Kashmir. www.kashmirlife.net/violence-against- womenin-kasmir-369.

Dabla BA. (2010). Emergence of late marriages in Kashmir. JoS KU, 3, 253-270.

Das NP \& Dey D. (1998). Female age marriage in India: Trends and Determinants. Demography India, 27(1), $91-115$ 
Ekman, P., \& Friesen, W. V. (1971). Constants across cultures in the face and emotion. Journal of Personality and Social Psychology, 17, 124-129. https://doi.org/10.1037/h0030377

Fussell, E. \& A. Palloni. (2004). Persistent Marriage Regimes in Changing Times. Journal of Marriage and Family, 66, 1201-13. https://doi.org/10.1111/j.0022-2445.2004.00087.x

Gupta, U., \& Singh, P. (1982). An exploratory study of love and liking and types of marriages. Indian Journal of Applied Psychology, 19, 92-97.

Guerin, B. (1993). Social Facilitation. Cambridge, UK: Cambridge University Press. https://doi.org/10.1017/CBO9780511628214

Hina Saleem, Dr. Abid Ghafoor Chaudhry, Adil Jabbar, Sara Mishal. (2015). Late Marriages and Infertility: An Anthropological Analysis on Health - The Explorer Islamabad. Journal of Social Sciences-Pakistan, 1(7), 246-250.

Irshad Ahmad Wani \& S.M. Zuber. (2013). Social Stratification in Kashmir: A Case Study of Caste, Class and Power in District Pulwama in South Kashmir. IOSR Journal Of Humanities And Social Science (IOSR-JHSS), 16(2), (Sep. - Oct. 2013), 08-18.

Kaur, R. (2004). Across-Region Marriages: Poverty, Female Migration and the Sex Ratio. Economic and Political Weekly, 39, 2595-603.

Kurdeck, L. A. (1999). The nature and predictors of the trajectory of change in marital quality for husbands and wives over the first 10 years of marriage. Developmental Psychology, 35, 1283-1296. https://doi.org/10.1037/0012-1649.35.5.1283

Lindholm, C. (1996). Caste in Islam and the Problem of Deviant Systems: A Critique of Recent Theory, in Frontier Perspectives: Essays in Comparative Anthropology, Oxford UP.

Muzaffar, Imran. (2013). Unemployment main reason for Late Marriages in Kashmir. GK Publications, Srinagar, Kashmir.

Mohiuddin, Yasmin. (1995). Country Ranking of Women's Status: An alternative Index. Pakistan Development Review Winter Edition, 341-355

Ruhee Rashid, Santosh Kumar Maharashi. (2015). Status of female education in Jammu \& Kashmir. American Journal of Educational Research, 3(6), 731-735.

Saroja, K., \& Surendra, H. S. (1991). A study of postgraduate students' endogamous preference in mate selection. Indian Journal of Behavior, 15, 1-13.

Srinivasan, P. \& G.R. Lee. (2004). The Dowry System in Northern India: Women's Attitudes and Social Change. Journal of Marriage and Family, 66, 1108-17. https://doi.org/10.1111/j.0022-2445.2004.00081.x

Senart, E. (1980). Caste in India: The Facts and the System. Metheun \& Co. London.

Umadevi, L., Venkataramaiah, P., \& Srinivasulu, R. (1992). A comparative study on the concept of marriage by Professional and non-professional degree students. Indian Journal of Behaviour, 16, $27-37$.

\section{Copyrights}

Copyright for this article is retained by the author(s), with first publication rights granted to the journal.

This is an open-access article distributed under the terms and conditions of the Creative Commons Attribution license (http://creativecommons.org/licenses/by/4.0/). 